College of William \& Mary Law School William \& Mary Law School Scholarship Repository

1963

\title{
Constitutional Separation of Church and State: The Quest for a Coherent Position
}

William W. Van Alstyne

William \& Mary Law School

\section{Repository Citation}

Van Alstyne, William W., "Constitutional Separation of Church and State: The Quest for a Coherent Position" (1963). Faculty Publications. 775.

https://scholarship.law.wm.edu/facpubs/775

Copyright c 1963 by the authors. This article is brought to you by the William \& Mary Law School Scholarship Repository. 


\title{
CONSTITUTIONAL SEPARATION OF CHURCH AND STATE: THE QUEST FOR A COHERENT POSITION
}

\author{
William W. Van Alstyne \\ The Ohio State University
}

Congress shall make no law respecting an establishment of religion, or
prohibiting the free exercise thereof ....

This clause of the First Amendment, recently applied by the Supreme Court to invalidate certain religious practices in the public schools, ${ }^{1}$ has called down a new storm over the Supreme Court. The storm has not consisted merely of the political bombast of predictable critics. ${ }^{2}$ Rather, it has included Dean Griswold of the Harvard Law School who perceived in the first school prayer case an unyielding and unwarranted absolutism in the position of the Court. ${ }^{3}$ It includes also highly regarded church figures, such as Episcopal Bishop Pike, who has called for a constitutional amendment to alter the Court's mandates. ${ }^{4}$ It has percolated within the law schools, ${ }^{5}$ and within the Court itself where

1 School District v. Schempp, and Murray v. Curlett, 374 U.S. 203, 83 S.Ct. 1560 (1963); Engel v. Vitale, 370 U.S. 421 (1962).

2 "They put the Negroes in the schools-now they put God out of the schools." Statement by G. W. Andrews, Representative from Alabama, New York Times, June 26, 1962, p. 1, col. 8. See also the remarks of Senators Eastland, Johnston, McClellan, Talmadge, Robertson, Stennis, and Beall, ibid., June 30, 1962, p. 20, cols. 2, 5, and sources cited $\rightarrow$ Kauper, "Prayer, Public Schools and the Supreme Court," University of Michigan Law Review, Vol. 61 (1963) p. 1031, n. 2; see also H.J.R. No. 21, a Joint Resolution adopted by the 105th General Assembly of Ohio (1963), memorializing the Ohio public school system "that daily prayer and Bible reading should be practiced in the schools of Ohio."

"Griswold, "Absolute is in the Dark," Utah Law Review, Vol. 8 (1963), p. 167.

${ }^{4}$ New York Times, July 14, 1962, p. 9, col. 2; Reader's Digest, 78-85 (1962). For an excellent news treatment of the Engel case, see CBS Reports, Storm Over the Supreme Court, Part Two, originally telecast on March 13, 1963. Reprints are available from the CBS Television Network.

${ }^{5}$ See, e.g., Kauper, op. cit. supra; Choper, "Religion in the Public Schools: A Proposed Constitutional Standard," University of Minnesota Law Review, Vol. 47 (1963), p. 329; Sutherland, "Establishment According to Engel," Harvard Law Review, Vol. 76 (1962), p. 25; Pfeffer, "Court, Constitution and Prayer," Rutgers Law Review, lengthy separate opinions were composed to clarify what has and what has not been done. ${ }^{6}$ Yet, even within the Court, as within the larger academic and public forums, wide disagreement remains as to the applied meaning of the opaque language of the religion clause. ${ }^{7}$

This article cannot quiet the storm over the Supreme Court, but it can make clear which parts of the storm are entitled to be taken seriously and which are merely bluster. Beyond this, there are more significant purposes to be served. The first of these is to make sense of existing cases in terms of some coherent doctrine, responsive to the First Amendment and possessing substantial predictive value: to describe the standard of church-state separation which the Supreme Court applies in fact. The second is to demonstrate that a number of open questions remain to be answered before a more precise boundary of church-state separation can be known. The third purpose of this article is to propose and to defend certain answers to

Vol. 16 (1962), p. 735; Kurland, "The Regents' Prayer Case: Full of Sound and Fury Signifying... ," 1962 The Supreme Court Review, p. 1.

${ }_{6}^{6}$ In Engel v. Vitale, above, note 1, three opinions covering thirty pages appeared, with two members of the Court not participating in the decision. In School District v. Schempp, also above, note 1 , four separate opinions spanning 117 pages of United States Reports were involved. The multiple opinions in the Sunday Closing Law cases span 220 pages and reveal breaches within the Court felt again this year in the four separate opinions filed in Sherbert $\mathrm{v}$. Verner, 374 U.S. 298, 83 S.Ct. 1790 (1963).

7 The disagreement is by no means confined to a split between the majority of eight and Mr. Justice Stewart who dissented. Mr. Justice Douglas apparently would apply the Establishment Clause whenever there is one cent of public funds involved. Mr. Justice Brennan would obviously uphold a vast number of practices unacceptable to Mr. Justice Douglas, and there are significant differences as well in the concepts of neutrality in the opinions of Mr. Justice Clark, in relation to those by Justices Goldberg and Harlan. 
the open questions, to provide the Court with a position which is both coherent and neutral.

\section{I}

A restatement of the Religion Clause to conform to the Court's response to the First Amendment is not without its difficulties; the Court has never used that clause to invalidate a single federal statute, notwithstanding the many substantial connections which continue to be maintained between organized religion and the federal government. Certain surface inconsistencies, moreover, appear among the several cases upholding certain federal laws which confer conspicuous benefits on some religious groups. ${ }^{8}$ All of the decisions invalidating laws because they either abridged the free exercise of religion, or tended to establish religion, have involved state laws only. ${ }^{9}$ And each of these decisions has relied upon an Amendment to the Constitution which itself makes no express mention of "religion" whatever and provides only the following vague statement:

[N]or shall any State deprive any person of life, liberty, or property, without due process of law ....

8 See, e.g., United States v. Ballard, 322 U.S. 78 (1944); Arver v. United States, 245 U.S. 366 (1918); Quick Bear v. Leupp, 210 U.S. 50 (1908); Holy Trinity Church v. United States, 143 U.S. 457 (1891); Bradfield v. Roberts, 175 U.S. 219 (1899); Davis v. Beason, 133 U.S. 333 (1890); Reynolds v. United States, 98 U.S. 145 (1879).

${ }^{9}$ See e.g., the Schempp, Murray and Engel cases cited above, note I; Torcaso v. Watkins, 367 U.S. 488 (1961); McCollum v. School Board, 333 U.S. 203 (1948), holding state laws invalid as an establishment of religion. Sherbert v. Verner, above, note 6; Jamison v. Texas, 318 U.S. 413 (1943); Largent v. Texas, 318 U.S. 418 (1943); Follett v. McCormick, 321 U.S. 573 (1944); Murdock v. Pennsylvania, 319 U.S. 105 (1943); Douglas v. Jeannette, 319 U.S. 157 (1943); Jones v. Opelika, 319 U.S. 103 (1943); Martin v. City of Struthers, 319 U.S. 141 (1943), holding state laws invalid as abridging the free exercise of religion. There has been a host of cases in which freedom of religion was involved, but where the decision was not in fact based on an "abridgment" theory. See, e.g., Lovell v. City of Griffin, 303 U.S. 444 (1938); Board of Education v. Barnette, 319 U.S. 624 (1943); Cochran v. La. State Bd. of Educ., 281 U.S. 370 (1930); Pierce v. Society of Sisters, 268 U.S. 510 (1925). For a superior discussion of these and related cases, see Kurland, Religion and the Law (Chicago, 1962).
In the process of interpreting this Amendment to make applicable against state government the full religion clause of the First Amendment, itself applicable only against Congress, ${ }^{10}$ the Court has rejected a number of arguments still troublesome to the historically minded. Successively, the Court considered and disposed of the following contentions: (1) the due process clause, as part of the Fourteenth Amendment, was ratified in 1868 merely to extend additional constitutional protection to Negroes beyond what the Reconstruction Congress believed had already been accomplished in the Thirteenth Amendment, and had no purpose to limit government power outside the race zone; (2) the clause, as it says, is concerned only with the integrity of the process or means by which decisions affecting life, liberty, or property are made, i.e., that those means conform with due process, and it has nothing to do with the substance of a legislative decision arrived at by an appropriate and reasonable procedure; (3) assuming there is a substantive due process aspect to the clause, however, an interest in religion is not within the kind of "liberty" contemplated; i.e., there was no incorporation of the First Amendment's religion clause into the due process clause; (4) assuming there was some incorporation, still, since the due process clause speaks of "liberty," only that part of the First Amendment protecting religious liberty is made applicable to states, and the establishment clause is not applicable. Consequently, if a state law does not impair anyone's liberty to worship as he pleases; there can be no complaint if it merely promotes religion or subsidizes religious interests, even though such practices might constitute an establishment of religion under the First Amendment. ${ }^{11}$

${ }^{10}$ Barron v. Baltimore, 7 Pet. 243, 8 L.Ed. 672 (1833); Permoli v. First Municipality, 44 U.S. (3 How.) 589 (1845).

${ }^{11}$ Historical analyses of the religion clause in the First Amendment, and of its application through the Fourteenth Amendment, include Healey, Jefferson on Religion in Public Education (1962); Murray, We Hold These Truths (New York; Shead and Ward, 1960); Howe, "The Constitutional Question," Religion and the Free Society, Vol. 49 (1958); Brady, Confusion Twice Confounded (1954); Pfeffer, Church, State and Freedom (Boston: The Beacon Press, 1962) pp. 124-33; O'Neill, Religion and Education Under the Constitution (New York, 1949); Corwin, The Supreme Court as a National School Board, A Constitution of Powers in a Secular State (1951); Stokes, Church and State in the United States, I, 
It is familiar learning that all of these arguments have been rejected, and that the First Amendment is regarded as fully and equally applicable against the states. Similarly, the Court has rejected the argument that the establishment clause was intended only to require that government be neutral among religions, rather than detached from religion itself, i.e., that laws of benefit to religion are constitutional when the benefit is extended on a nonsectarian or nonpreferential basis sufficient to guard against establishing any one church as the state religion. The rejection of this and the preceding arguments has now become so consistent and so emphatic that there is no practical benefit in re-evaluating them once again. Since 1947, the Court has heard eleven cases involving challenges to state laws where the challenges were based on the establishment clause of the First Amendment. ${ }^{12}$ In nearly every case, the arguments summarized above were elaborately presented in behalf of the state. While only five of the eleven cases actually went against the state in terms of the decision, in no case did the Court sustain a law

537-61 (1950); Parsons, The First Freedom (1948); Bryce, The American Commonwealth (New York, 1914), II, 763-95; Story, Commentaries on the Constitution of the United States (Boston, 1865), III, § 1865 et seq.; Murray, "Law or Prepossessions?," Law and Contemporary Problems, Vol. 14 (1959), p. $: \rightarrow$ Katz, "Freedom of Religion and State Neutrality," University of Chicago Law Review, Vol. 20 (1953), p. 4: $\rightarrow$ Pfeffer, "Church and State: Something Less than Separation," University of Chicago Law Review, Vol. 19 (1951) p. 1; Lardner, "How Far Does the Constitution Separate Church and State?," this Review, Vol. 45 (1951), p. 110; Konvitz, "Separation of Church and State: The First Freedom," Law and Contemporary Problems, Vol. 14 (1949), p. 44; U.C.L.A. Law Review, Vol. 9 (1962), pp. 495, 499.

${ }^{12}$ In addition to the five cases cited in note 9 above, invalidating state laws establishing religion, the Court has sustained laws against such a challenge in the following six cases: McGowan v. Maryland, 366 U.S. 420 (1961), (four cases consolidated); Zorach v. Clauson, 343 U.S. 306 (1952); Everson v. Board of Education, 330 U.S. 1 (1947). In addition, two members of the Court invoked the establishment clause this year in Sherbert v. Verner, above, note 6 , and there are other cases where the issue was not raised or not heard, e.g., Cochran v. La. State Bd. of Education, 281 U.S. 370 (1930); Doremus v. Board of Education, 342 U.S. 429 (1952); Poe v. Ullman, 367 U.S. 497 (1961). on the basis of any of the above arguments. That these arguments are no longer presentable in the Court is clear from the following abrupt statements from the majority opinion in this year's school prayer cases:

First, this Court has decisively settled that the First Amendment's mandate that "Congress shall make no law respecting an establishment of religion, or prohibiting the free exercise thereof" has been made wholly applicable to the states by the Fourteenth Amendment.

....

Second, this Court has rejected unequivocally the contention that the establishment clause forbids only governmental preference of one religion over another. ${ }^{13}$

What the Court has done, instead, is to treat the two aspects of the religion clause as stating a single principle applicable to federal and state government. One aspect is the admonition that government may not act to burden the free exercise of religion. The other is that government may not act to benefit religion. The free exercise and establishment subclauses, taken together, are thus designed to commit government to a studied neutrality with respect to religion while government attempts to fulfill its numerous delegated, implied, and reserved secular responsibilities. ${ }^{14}$ Distilled

${ }^{13}$ School District v. Schempp, 374 U.S. 203, 215-16 (1963).

${ }^{14} I d$. at 226: "We have come to recognize through bitter experience that it is not within the power of government to invade that citadel, whether its purpose or effect be to aid or oppose, to advance or retard. In the relationship between man and religion, the State is firmly committed to a position of neutrality."

See also Everson v. Board of Education, 330 U.S. 1, 52 (1947) (dissenting opinion by $\mathrm{Mr}$. Justice Rutledge): "The sphere of religious activity, as distinguished from the secular intellectual liberties, has been given the two-fold protection and, as the state cannot forbid, neither can it perform or aid in performing the religious function. The dual prohibition makes that function altogether private."

Professor Kurland has attempted to synthesize the duality of the First Amendment in the following terms (Religion and the Law [1962] pp. 18, 112): "The freedom and separation clauses should be read as stating a single precept: the government cannot utilize religion as a standard for action or inaction because these clauses, read together as they should be, prohibit classification in terms of religion either to confer a benefit or to 
from the opinions of the Supreme Court, the First and Fourteenth Amendments may be read as providing: in the fulfillment of its proper functions, government should choose from among feasible alternatives, if any, those means which result in the least advantages and disadvantages to religion. ${ }^{15}$

The political objectives of the religion clause consequently include the following:

1. to insulate governmental processes from distinctly religious controversy, by restricting the power of government in a manner which leaves religious and anti-religious organizations without special incentive or temptation to exert institutional pressures on those processes..$^{16}$

2. to protect the private exercise of religious commitments from destruction, manipulation or seizure by the irreligious, by disabling government from acting with deliberate hostility to religion;

3 . to a void internecine strife among religions by disabling government from assisting or

impose a burden." There are difficulties in the application of this particular statement, however, and for that reason I have employed a slightly different statement in the text, infra. See Kauper, "Religion and the Law: A Review," Texas Law Review, Vol. 41 (1963), p. $4 \rightarrow$ Pfeffer, "Religion-Blind Government: A Review," Stanord Law Review, Vol. 15 (1963), p. 389.

${ }^{15}$ See School District v. Schempp, above, note 1, at p. 222: "The test may be stated as follows: what are the purpose and the primary effect of the enactment? If either is the advancement or inhibition of religion then the enactment exceeds the scope of legislative power as circumscribed by the Constitution."

${ }^{16}$ The concern to limit government from having powers which would provide a temptation for organized religions is evident from the dicta of the Court: "[T]he effect of the religious freedom amendment to our Constitution was to take every form of propagation of religion out of the realm of things which could directly or indirectly be made public business.... It was intended not only to keep the states' hands out of religion, but to keep religion's hands off the state, and, above all, to keep bitter religious controversy from getting control of public policy or the public purse." Everson v. Board of Education, 330 U.S. 1, 26, (1947) (dissenting opinion). See also $M c$ Gowan v. Maryland, 366 U.S. 420, 430 (1961): "(T)he writings of Madison, who was the First Amendment's architect, demonstrate that the establishment of a religion was equally feared because of its tendencies to political tyranny and subversion of civil authority." harming any one or more religions more than others;

4. to respect the integrity of non-believers by disabling government from lending its authority in behalf of religion. ${ }^{17}$

${ }^{17}$ In view of the trappings of religiosity in public life, it is commonly supposed that the First Amendment is unconcerned with protecting atheists and agnostics. Such a view is comforted, no doubt, by certain congressional acts within the past decade. In 1954, "under God" was inserted into the pledge of allegiance. 36 U.S.C. $\S 172$ (1958). In 1956, "In God We Trust" was adopted as the national motto by joint resolution. 70 Stat. 732. In 1955, "In God We Trust," first authorized for imprinting on coins in 1865 (13 Stat. 517, 518), was prescribed for all currency and coins. 69 Stat. 290. In 1952, Congress memorialized the President to proclaim a National Day of Prayer each year. 36 U.S.C. § 185.

The lingering view that the First Amendment is merely neutral among religions also finds support in an unguarded dictum by Mr. Justice Douglas, the consequences of which were ably traced by Sorauf, "Zorach v. Clauson: The Impact of a Supreme Court Decision," this Review, Vol. 53 (1959), p. 777. The dictum, from Zorach v. Clauson, 343 U.S. 306, 314-15 (1952), was this: "We are a religious people whose institutions presuppose a Supreme Being. ... When the state encourages religious instruction or cooperates with religious authorities adjusting the schedule of public events to sectarian needs, it follows the best of our traditions."

Compare with these, the following statements by the Court: Torcaso v. Watkins, 367 U.S. 488 , 495 (1961): "We repeat and again reaffirm that neither a State nor the Federal Government can constitutionally force a person 'to profess a belief or disbelief in any religion.' Neither can constitutionally pass laws or impose requirements which aid all religions as against non-believers, and neither can aid those religions based on a belief in the existence of God as against those religions founded on different beliefs." Also, Zorach v. Clauson, 343 U.S. 306, 319, 325 (1952), (dissenting opinions by Mr. Justice Black and Mr. Justice Jackson, respectively): "The spiritual mind of man has thus been free to believe, disbelieve, or doubt, without repression, great or small, by the heavy hand of government.... The day that this country ceases to be free for irreligion it will cease to be free for religion-except for the sect that can win political power." And Everson v. Board of Education, 330 U.S. 1, 15-16 (1947): "Neither [a state nor the federal government] can pass laws which aid one religion, aid all religions, or prefer one religion over an- 
The operation of this standard in the eleven cases decided by the Court under the establishment clause may help to indicate its dimensions. In Everson v. Board of Education, ${ }^{18}$ the Court reviewed an ordinance of a New Jersey township which provided for the reimbursement of the parents of public and parochial school children for the cost of bus transportation to and from school. The average reimbursement was $\$ 40$ per family each year. These payments, made from public funds, were attacked on the grounds that they constituted a tax subsidy which relieved Catholic parents of costs they would otherwise have to meet from private sources and which allegedly constituted impermissible aid tending to establish religion. Writing for a majority of five, Mr. Justice Black conceded that the arrangement did involve a measure of "aid" to religion, but he declared the ordinance to be valid on the grounds that such aid was unavoidable and entirely incidental to the primary and independent secular purposes of the ordinance, e.g., to promote safety in transportation, and the education and welfare of children. Since parochial school children were no less likely to encounter traffic hazards than public school

other. Neither can force nor influence a person to go to or to remain away from church against his will or force him to profess a belief or disbelief in any religion. No person can be punished for entertaining or professing religious beliefs or disbeliefs, for church attendance or non-attendance."

While no one may have "standing" to secure judicial review of Congress's religious obeisances, it is extremely difficult to reconcile the religious slogans enacted by Congress into law, with the following declaration by Mr. Justice Frankfurter, McGowan v. Maryland, 366 U.S. 420, 465 (1961): "The Establishment Clause withdrew from the sphere of legitimate legislative concern and competence a specific, but comprehensive, area of human conduct: man's belief or disbelief in the verity of some transcendental idea and man's expression in action of that belief or disbelief. Congress may not make these matters, as such, the subject of legislation, nor, now, may any legislature in this country. Neither the National Government nor, under the Due Process Clause of the Fourteenth Amendment, a State may, by any device, support belief or the expression of belief for its own sake, whether from conviction of the truth of that belief, or from conviction that by the propagation of that belief the civil welfare of the State is served, or because a majority of its citizens, holding that belief, are offended when all do not hold it.

${ }^{18}$ Loc. cit. supra, note 12. children, and since the parochial schools' curricula satisfied New Jersey's secular state standards of education, it was reasonable for a township to be as concerned with their general welfare as with the welfare of other school children, and to treat them equally. The analogy was drawn to other municipal services: city policemen and firemen protect churches and their parishoners just as they protect department stores and their customers. Since these are protected not because they are religious, but solely because, their religion aside, they are otherwise simply members of a larger class whose welfare and protection is the proper concern of government, no violation of the establishment clause is involved. In terms of the standard offered above, the decision appears defensible in these terms: It is a proper function of government to encourage education and to promote safety in the transportation of children. Recognizing that government cannot operate in a vacuum, i.e., with literally no effect on matters which incidentally assist or injure religious interests, those secular purposes may be fulfilled by public reimbursement of the costs of school transportation without violating the establishment clause.

In McCollum $v$. Board of Education, ${ }^{19}$ a school board permitted various churches to conduct religious classes on school property and during the regular school day. Children not choosing to attend such a class were obliged to remain on campus, in a study hall. Noting that the arrangement benefited religion by providing free facilities for religious indoctrination, and noting too that the program involved a measure of coercion on impressionable youngsters, the Court was obliged to determine whether these benefits, like those in Everson, were merely incidental to some secular purpose, or at least were no more than an unavoidable consequence of the fulfillment of some purpose otherwise within the power of government to promote. The released-time courses were not, however, courses about religion which might be defended simply as constituting part of a general liberal education. ${ }^{20}$ Since there was no primary and independent secular purpose being fulfilled through the released time program, the

${ }^{10} 333$ U.S. 203 (1948).

${ }^{20}$ See School District v. Schempp, above, note 1, at p. 225: "It certainly may be said that the Bible is worthy of study for its literary and historic qualities. Nothing we have said here indicates that such study of the Bible or of religion, when presented objectively as part of a secular program of education, may not be effected consistent with the First Amendment. 
arrangement was invalidated as an unconstitutional establishment of religion. ${ }^{21}$

The four Sunday Closing Law Cases ${ }^{22}$ sus-

${ }^{21}$ Analytically, the three school prayer cases are scarcely more difficult on the merits than McCollum. These cases severally involved a prayer composed by state officials and required to be recited by school children other than those excused on written request of their parents, and the recitation of the Lord's Prayer or the reading of sections from the Bible or Jewish scriptures, without comment, at the beginning of each school day. Here, too, participation was required by students not excused on written request of their parents, and the religious exercise was itself required by state law or school board regulation. While markedly less financial aid was involved in these programs than in $\mathrm{McCollum}$, since the time taken each day for prayers or bible reading consumed a bare moment or two, the arrangement still involved substantial aid to religion. Students doubtless felt some compulsion to participate, and the prestige of school authorities employed in a repetitious ritual and the authoritarian atmosphere of the schoolroom would influence many youngsters. The inculcation of religion as distinguished from teaching about religion in courses on literature or history, moreover, is clearly not among the "proper functions" of government. See discussion, notes 17-20, supra. Consequently, it is easy to appreciate the decision of the Court holding these practices invalid under the test described above, even assuming the amount of aid to religion was relatively slight; such aid was not incidental to any primary or independent secular purpose which would save the scheme. (The school board alleged, however, that the religious practices did serve independent secular purposes. This matter is considered infra, text, at $\mathrm{n}$. 39. See also Choper, "Religion in the Public Schools: A Proposed Constitutional Standard," Minnesota Law Review, Vol. 47 (1963) p. 329.)

For similar reasons, the religious oath of office, considered in Torcaso v. Watkins, 367 U.S. 498 (1961), was invalidated under the establishment clause. Maryland law required, as a condition of office, that notaries public subscribe to an oath affirming a belief in a Supreme Being. The coercion of such a religious expression, unsupported by any primary and independent secular purpose, resulted in a unanimous decision against its constitutionality.

${ }^{22}$ McGowan v. Maryland, 366 U.S. 420 (1961): Two Guys from Harrison-Allentown, Inc. v. McGinley, 366 U.S. 582 (1961); Braunfeld v. Brown, 366 U.S. 599 (1961); Gallagher v. Crown Kosher Super Market, 366 U.S. 617 (1961). tained state laws prohibiting commercial activity on Sunday, even where the law made no exception for Sabbatarians while exempting an odd collection of sales transactions relating to presumed emergency needs, recreation or works of charity. As in Everson, the Court did not deny that these laws conferred a benefit on religion by placing the power of government behind the strictly religious teaching of some Christian sects opposed to labor on the Lord's Day. Moreover, it conceded as well that in some cases at least, the impetus for such laws had been frankly religious in character, i.e., religious organizations had lobbied successfully for such statutes. Seemingly, such laws should be unconstitutional, as they violate the test and offend the political objective of the establishment clause to keep government from becoming the captive of organized religion.

Nevertheless, the statutes were upheld in all four cases. As in Everson, the result turned on a finding that the supposed benefit to religion which flowed from these laws was merely incidental to a primary and independent secular objective, properly within the police power of the state. These objectives were essentially like those furthered by a variety of laws protecting the health and general welfare of working people, e.g., minimum age and wage laws, maximum hours laws, collective bargaining laws, etc. It was equally consistent with the general welfare to set aside one day in seven, to assure each person an opportunity for psychological and physical recuperation, to allow families and friends to come together, and generally to insulate the community from the hectic drudgery and raucous noise of the work week. The fact that the particular day set aside by law, Sunday, coincided with the religious preference of dominant organizations, was not enough to convert the law into an establishment of religion:

[I]t is equally true that the Establishment Clause does not ban federal or state regulation of conduct whose reason or effect merely happens to coincide or harmonize with the tenets of some or all religions. In many instances, the Congress or state legislatures conclude that the general welfare of society, wholly apart from any religious considerations, demands such regulation. ${ }^{23}$

The eleventh case, Zorach v. Clauson, ${ }^{24}$ decided in 1952, is a variant of the released-time program condemned in the McCollum case. The arrangement in Zorach differed principally in that: (1) no financial aid was involved be-

${ }^{23}$ McGowan v. Maryland, 366 U.S. at 442.

${ }^{24} 343$ U.S. 306 (1952). 
cause the religious classes were held off campus and no school personnel were involved; (2) less governmental sanction was placed behind the religious views presented in the off-campus classes, since the classes were not conducted under school auspices and the participating children would not regard the religious instructor with the same submissiveness as they might their teacher within the regular classroom. Still, some evidence indicated that because non-participating students were required to remain in their classrooms, government did aid religion by subtly coercing student participation. But even more critical, the Zorach arrangement showed no more of a substantial, or primary and independent secular purpose being served by the released-time program than in McCollum itself. Consequently, this case is often regarded as a departure from the standard, and as an aberration not likely to be followed today. ${ }^{25}$

${ }^{25} \mathrm{It}$ is arguable, however, that Zorach is defensible according to the standard, when one recalls that the unitary precept of the First Amendment is that government should act neither to benefit nor to burden religion. If one focusses not exclusively on the released-time program, but on the net effect of government having embarked on a compulsory education program, Zorach becomes more understandable in these terms: by enacting laws to require children to attend schools during most of the day, the state initially made it more difficult than before for those students to attend religious classes during those same days. By thereafter scheduling its own secular classes to accommodate those students who wished to attend religious classes off campus, the state merely acted to redress the balance, i.e., it restored to the students an opportunity to exercise the religious freedom which they enjoyed before regular school attendance was required,

To a large extent, however, this same argument was also involved in the school prayer cases where a Zorach rationale was rejected by a majority of eight members of the Court. The lone dissenting opinion, by Mr. Justice Stewart, argued that the compulsory school attendance law initially operated to make it more difficult for children to engage in the free exercise of religion, i.e., that it tended to abridge religious activities: "[A] compulsory state educational system so structures a child's life that if religious exercises are held to be an impermissible activity in schools, religion is placed at an artificial and state-created disadvantage. Viewed in this light, permission of such exercises for those who want them is necessary if the schools are truly to be neutral in the matter of
With the possible exception of Zorach, however, all of the establishment cases are seemingly consistent with the standard of neutrality which we have derived from the Court's several opinions. Even so, there is widespread disagreement within the Court and among the commentators as to the constitutionality of a vast number of existing and proposed church-

religion." School District v. Schempp, above, note 1 , at p. 313 .

Nevertheless, more than "neutrality" was involved in the prayer cases. In the following respects, the program as it was administered did more than merely restore the opportunity children might have had to exercise religious prerogatives in the absence of any compulsory school attendance: (a) The prayer in Engel was obviously not of each student's or each family's private choosing, but was composed by state officials and was sectarian in character; it read as follows: "Almighty God, we acknowledge our dependence upon Thee, and we beg Thy blessings upon us, our parents, our teachers and our country." The Court has defined religion broadly, to include some nontheistic and many relatively small sects. See text at n. 32, infra. In this view, the Engel prayer becomes sectarian, e.g., the invocation of God is incompatible with nontheistic sects, an oral prayer is disliked by Quakers, the presumed value of prayer itself, describing the relationship between man and God as one of supplication and paternal response, and the use of a prayer to favor a particular country-all of these are variously offensive to a number of religions. (b) The prayer and scriptures in Schempp and Murray, while obviously not composed by the state, were prescribed by the state and were equally sectarian. (c) The excusal procedure, as noted by $\mathrm{Mr}$. Justice Brennan, School District v. Schempp, supra, at pp. 288; itself tended to coerce students at least more than were there no school environment. (d) Some tax funds contributed by people opposed to the prayers were involved in the salaries of the teachers and provision of the classrooms, at least more than were there no school program, with each family being left to its own resources: $i d$. at p. 229-30 (where appears the separate opinion by Mr. Justice Douglas): "[T]he present regimes must fall under that clause for the additional reason that public funds, though small in amount, are being used to promote a religious exercise.... Such contributions may not be made by the State even in a minor degree without violating the Establishment Clause. It is not the amount of public funds expended; as this case illustrates, it is the use to which public funds are put that is controlling." (e) Conducting daily religious exercises in a classroom and under the direction of teachers provided an atmosphere in 
state relationships..$^{26}$ With respect to financial relationships, questions continue to arise concerning the tax exemptions accorded church property, parochial schools, the income of churches, and church supported and supporting enterprises, as well as the tax deductibility of contributions to religious organizations. ${ }^{27}$

which the students might well be more substantially influenced than would be the case if there were no school system, and religious instruction left to each family and church. On balance the prayer cases appear to have been decided correctly.

Not all of the aggravating elements of the prayer cases were present in Zorach, of course, and thus the case may still be as valid as Mr. Justice Brennan has recently suggested, $i d$. at p. 262: "The deeper difference was that the McCollum program placed the religious instructor in the public school classroom in precisely the position of authority held by the regular teachers of secular subjects, while the Zorach program did not."

Nevertheless, the arrangement even in Zorach actually did more than restore opportunities for religious endeavors which young people would theoretically have had in the absence of compulsory school attendance laws, and for this reason, the case is of doubtful authority. If the purpose of the released time program was merely to allow students to follow their own, or their family's inclination to have them attend religious classes during the week at some church, that purpose would be adequately served by having the school release all students at certain specified times, leaving to each student and his parents the decision as to how that released time should be spent. In Zorach, however, those students not attending religious classes were obliged to remain in their regular classrooms, and careful records of released students were maintained to make certain that they did attend the religious classes. The net effect of the program was consequently to ply a subtle coercion in favor of attendance at the religious classes, and not merely to provide students with the same freedom of choice they would have enjoyed had they all simply been dismissed from school on their own, or their family's recognizance. See the several dissenting opinions in Zorach v. Clauson, beginning at 343 U.S. 315.

${ }^{26}$ See n. 5, supra; Pfeffer, "Some Current Issues in Church and State," Western Reserve Law Review, Vol. 13 (1961), p. 9; Kauper, "Church and State: Cooperative Separation," Michigan Law Review, Vol. 60 (1961), p. 1; Kurland, Religion and the Law (1962).

${ }^{27}$ See Paulsen, "Preferment of Religious Institutions in Tax and Labor Legislation," Law
Equally, the inclusion of parochial schools in a program of federal aid for education has raised questions, ${ }^{28}$ as has existing federal assistance to church-operated hospitals, ${ }^{29}$ the salaries of congressional and military chaplains, the cost of military chapels, and the federal "hot lunch" program which serves parochial as well as public schools. With respect to the regulatory authority of government, disagreement abounds as to the constitutionality of the conscientious-objector exemption to the draft law, anti-contraceptive laws, Sunday closing laws, religious holidays, and the fragments of religiosity in public life such as the use of the phrase "under God" in the pledge of allegiance, and "In God We Trust" in the national motto and on all U.S. currency..$^{30}$

These disagreements seem likely to continue, at least until the Court clarifies several particular parts of the test. Certain hard questions have by no means been finally resolved. Principal among the unsettled ambiguities of the church-state standard of the First Amendment are these:

and Contemporary Problems, Vol. 14 (1949), p. 144; Stimson, "The Exemption of Property From Taxation in the United States," Minnesota Law Review, Vol. 18 (1934), p. 411; Note, "Constitutionality of Tax Benefits Accorded Religion," Columbia Law Review, Vol. 49 (1949), p. 968; Comment, "State Tax Exemptions and the Establishment Clause," Stanford Law Review, Vol. 9 (1957), p. 366. See also Arvo Van Alstyne, "Tax Exemption of Church Property," Ohio State Law Journal, Vol. 20 (1959), p. 461; Orinan, Religion, the Courts, and Public Policy (1903), pp. 1-38.

${ }^{28}$ Compare Butler and Scanlan, "Wall of Separation-Judicial Gloss on the First Amendment," Notre Dame Lawyer, Vol. 37 (1962) p. 288 with Pfeffer, "Federal Funds for Parochial Schools? No.," Notre Dame Lawyer, Vol. 37 (1962), p. 309; Konvitz, "Separation of Church and State: The First Freedom," Law and Contemporary Problems, Vol. 14 (1949), p. 44.

${ }^{29}$ See Bradfield v. Roberts, 175 U.S. 291 (1899), sustaining such an arrangement. This case may also be pertinent to discussions of federal aid for education.

${ }^{30}$ Compare Kurland, Religion and the Law (1962), pp. 40-41 with Conklin, "Conscientious Objector Provisions: A View in the Light of Torcaso v. Watkins," Georgia Law Journal, Vol. 51 (1963), p. 252. Compare the separate opinion of Mr. Justice Douglas, Engel v. Vitale, 370 U.S. 421,437 (1962) with the dissenting opinion by Mr. Justice Stewart at p. 444, and see the opinion by Mr. Justice Brennan in School District v. Schempp, supra, at pp. 296-304. 
1. By what means are secular interests of government rationally distinguishable from religious interests which government may neither abridge nor establish?

2. Assuming there is a tenable distinction, to what extent will the Court attempt to determine which among several intertwined secular and religious objectives the legislature was primarily attempting to promote in fact?

3. Assuming that a particular item of secular legislation also produces a significant advantage or disadvantage to religion, how feasible must alternative means of accomplishing the secular objective without the same effect on religion be, before the Court will hold that the availability of those alternative means operates to invalidate the particular scheme elected by a legislature?

4. In determining whether religion has been burdened or benefited by a particular law, to what extent will the Court review related laws to measure the net effect of the broader governmental activity?

The remainder of this article will attempt to illustrate these problems and explore some suggestions which may be useful in their solution.

\section{II}

Separating Secular from Religious Objectives. ${ }^{31}$ In Torcaso v. Watkins and School District $v$. Schempp, the Court observed that "religion" is not merely co-extensive with the systematic theologies of the most prominent religious organizations in American such as Protestantism, Catholicism, and Judaism. Rather, religion includes the beliefs of at least eightythree separate religious bodies with memberships in the United States exceeding 50,000, including a number of nontheistic religions such as Ethical Culture and Secular Humanism. ${ }^{32}$ The inclusion of these groups is, of course, unsurprising; it is easily argued that there are philosophic systems in the United States with far fewer than 50,000 adherents which are equally entitled to be recognized as

s1 "[T]he line which separates the secular from the sectarian in American life is elusive." Mr. Justice Brennan, in School District v. Schempp, supra, at p. 231. For thoughtful consideration of this problem, see Kauper, "Church and State: Cooperative Separatism," Michigan Law Review, Vol. 60 (1961), p. 1, 22; Kauper, "Separation of Church and State-A Constitutional View," Catholic Lawyer, Vol. 9 (1963), pp. 32, 41.

32367 U.S. at 495 n. $11 ; 374$ U.S. at 214. "religions" for constitutional purposes. ${ }^{33}$ Nevertheless, even the limited breadth of the Supreme Court's definition creates a grave theoretical problem in the enforcement of the First Amendment, because the scope of religious interest as thus defined frequently makes it nearly impossible to distinguish between religious objectives which government is not supposed to establish or abridge, and secular objectives which it is free to accomplish by law.

The reserved powers of the states, for instance, are frequently declared to include the power to promote the health, safety, morals and general welfare of the people. In the exercise of these powers, a variety of states have adopted anti-discrimination laws, anti-obscenity laws, anti-contraceptive laws, and Sunday closing laws. While some of these laws may find support among persons who claim they are not at all religious, many more people support and agitate for such legislation because they believe such laws to be religiously desirable. Manifestly, to the extent that the states employ their powers to enact and to enforce these laws, they are necessarily tending to establish what is partly a religiously supported and supportive arrangement. That the arrangement may also have non-religious utility, in the sense that it is supported by some people not asserting a distinctly religious interest in the matter, does not make the resulting law significantly less of an establishment of religion in public life. A hardboiled theory of the Establishment Clause might suggest that all such laws are unconstitutional.

Nevertheless, one is immediately repelled by this suggestion, if only because it would necessarily invalidate the great majority of all welfare legislation and virtually paralyze government from performing useful services in general. In fashioning a pragmatic response to this issue, the Supreme Court has generally defined "religion" in two different ways under the First Amendment. For purposes of the Establishment Clause, religion has pretty well

${ }^{33}$ Julian Huxley, for instance, while disbelieving in a God, systematic theology, or even a general metaphysics, nevertheless describes his own commitment to evolutionary humanism as a religion. Huxley, Religion Without Revelation (1957), pp. 20, 194. For equally broad definitions by American philosphers and theologians, see James, Essays in Pragmatism (Castell ed., 1952), pp. 122-24; Dewey, Intelligence in the Modern World (Ratner ed. 1939), p. 1036; Tillich, "The Sum and Substance," University of Southern California Alumni Review, Vol. 44 (1963), pp. 11, 13. 
been confined to the preachments of organized groups-which groups may attempt to manipulate the civil process to establish their own, distinct theology through the law or attempt to wrest benefits from the civil process which are of special concern to them and not shared by a cross-section of persons outside their particular church or band of churches. The laws requiring the saying of prayers or the reading of scriptures in class, for instance, are a clear example of distinct efforts at institutional religious aggrandizement, not primarily serving any needs or wants of others. More to the point, if the Court were to find such practices compatible with the Establishment Clause, such a finding would manifestly undercut the objective of the Amendment to withdraw incentives from religious organizations to exert institutional pressures on the civil process.

Where the legislation in question is not in fact the consequence of particular institutionalized religious pressure, however, its coincidental harmony with, and establishment of, religious values will not be regarded as offensive to the Establishment Clause. The clearest statement of this position is found in $\mathrm{Mr}$. Justice Warren's dictum in McGowan:

[T]he "Establishment" Clause does not ban federal or state regulation of conduct whose reason or effect merely happens to coincide or harmonize with the tenets of some or all religions. In many instances, the Congress or state legislatures conclude that the general welfare of society, wholly apart from any religious considerations, demands such regulation. Thus for temporal purposes, murder is illegal. And the fact that this agrees with the dictates of the Judaeo-Christian religions while it may disagree with others does not invalidate the regulation. So too with the questions of adultery and polygamy. Davis v. Beason, 133 U.S. 333; Reynolds v. United States, supra. The same could be said of theft, fraud, etc., because those offenses were also proscribed in the Decalogue..$^{34}$

Intellectually, the Chief Justice doubtless overstated the case in asserting that such legislation is adopted "wholly apart from any religious considerations," for some more or less privately held religious consideration probably underlies the value judgments held by the great majority of electors and legislators who created the law. ${ }^{35}$ Especially was this so in the very Sunday

34 McGowan v. Maryland, 366 U.S. at 442.

${ }^{35}$ See n. 42, supra, and Mr. Justice Frankfurter, in McGowan v. Maryland, 366 U.S. 420, 461 (1961): "Religious beliefs pervade, and religious institutions have traditionally regulated, virtually all human activity."
Closing Law Cases in which this statement appeared. Nevertheless, the practical effect of the Chief Justice's proffered distinction is probably the best compromise we can expect; it guards against militant church pressures while permitting laws which do not appear to be the particular result of such institutional pressure. This is not to assert, however, that laws which have some hypothetical value beyond serving the self-aggrandizing institutional interests of one or more churches are automatically valid under the Establishment Clause, as the discussion in the following sections may indicate. It is only to assert that there is a clearer offense to the political objectives of the Clause when a given law results from, or tempts, institutional pressure from organized religion and does not merely coincide with matters of religious concern.

Religion may be a more inclusive thing, however, when the issue is whether freedom to exercise religion has been abridged rather than whether religion has been established. In this connection, the Court's suggestion that "religion" is not merely co-extensive with the better established and more highly organized sects, may be taken more seriously. For while the primary (although not exclusive) concern of the Establishment Clause is to resist the importunities of distinctly institutional religious pressures, the concern of the abridgment clause is to protect individual prerogatives of conscience, ${ }^{36}$ and not merely to protect the freedom of institutionalized religion or conscience. Saluting the flag, for instance, may not involve either marked assistance or harm to the vast majority of people or to a church as such, but the offense it gives to some who conscientiously oppose such a practice has been held sufficient that the flag salute cannot be compelled by law. ${ }^{37}$

Even so, at some point individual assertions of conscience, absolutely sheltered by the abridgment clause, could equally frustrate any significant governmental activity just as a broad definition of religion would bar other

${ }^{36}$ School District v. Schempp, supra, at p. 22223: "The Free Exercise Clause . . . withdraws from the legislative power, state and federal, the exertion of any restraint on the free exercise of religion. Its purpose is to secure religious liberty in the individual by prohibiting any invasion thereof by civil authority."

${ }^{37}$ See Board of Education v. Barnette, 319 U.S. 624 (1943), overruling Minersville School District v. Gobitis, 310 U.S. 586 (1940). As a technical matter, however, the majority opinion in Barnette was not based on an abridgment theory. 
state action because it tended to establish religion. In the face of religious objections to medicine, for instance, laws requiring vaccination against contagious diseases, or fluoridated water systems which all must use, constitute a measure of abridgment. In these matters, the Court may be expected to hold that where the governmental activity is broadly supported by democratically determined objectives which are not anti-religious by design and which cannot so feasibly be carried on without applying to all persons, an incidental abridgment of some religious interests is constitutionally permissible. ${ }^{38}$ Where the public purpose can be substantially served without discommoding personal religious interests, however, the abridgment clause may operate to shelter even the unorthodoxies of small minorities or single, unorganized individuals. Because the abridgment clause is more designed to protect the individual as well as the church from the state, while the establishment clause is more concerned with insulating the civil process from manipulation by organized religion, we may reasonably expect the Court to define "religion" more broadly in the context of alleged abridgments.

Distinguishing Actual Purposes from Rationalized Purposes. Most of the laws reviewed by the Court under the Establishment Clause, and many still to be reviewed, produce a multiplicity of effects. Some of these effects are clearly secular, according to common understanding, and others are clearly religious. In Everson, as we have noted, one effect of the reimbursement plan was to encourage safe transportation and to reduce traffic hazards for children, something clearly within the competence of government to accomplish. At the same time, it was also true that another effect was to subsidize religious instruction, by relieving parents of the cost of transporting their children to parochial schools. In McGowan, as we have noted, one effect was to promote the general welfare by guaranteeing one day each week free from common labor. At the same time, the arrangement did throw the weight of government behind those religions that seek the observance of Sunday strictly for religious reasons. To a lesser extent, the prayer cases involved entwined secular and religious objectives; the use of prayers at the beginning of each school day was defended before the Court partly on the grounds that it served the follow-

28 See, e.g., The Selective Draft Law Cases, 245 U.S. 366 (1918); Prince v. Massachusetts, 321 U.S. 158 (1944); Breard v. Alexandria, 341 U.S. 622 (1951). For a more questionable instance, see In re Summers, 325 U.S. 561 (1945). ing independent and salutary secular purposes: to foster harmony and tolerance among the pupils; to cause each individual pupil to constrain his overt acts and consequently to conform to accepted standards of behavior during his attendance at school; to enhance the authority of the teacher; and to inspire better discipline. ${ }^{39}$ Similarly, the pledge of allegiance arguably serves secular as well as religious purposes, e.g., to inculcate a spirit of nationality, loyalty, and patriotism in the young, or "merely to recognize the historical fact that our Nation was believed to have been founded 'under God.' "40 Federal aid proposals, inclusive of parochial schools, may be defended as promoting education to better the economy, education and defense of the country, or criticized as subsidizing the inculcation of religion in parochial schools. ${ }^{41}$

Since the operation of these laws does produce multiple effects, it is obvious that the constitutionality of a particular scheme may well depend upon the judicial characterization as to which of these is the predominant effect. ${ }^{42}$ If the Court describes the law to emphasize only its secular objectives, suddenly the constitutional objection may virtually disappear. On the other hand, if the question is phrased to emphasize the effect on religion, the law in question is made to appear unconstitutional on its face. The selective use of legislative effects is manifest in the differing characterizations of the law in Everson. Mr. Justice Black viewed the law as though the township council had been solely concerned with the incidence of traffic accidents among school children, and had acted in response to a popular demand for municipal protection:

[New Jersey's] legislation, as applied, does no more than provide a general program to help parents get their children, regardless of their religion, safely and expeditiously to and from accredited schools. ${ }^{43}$

${ }^{39}$ See the Schempp case, supra, at pp. 223,278-79.

${ }^{10} \mathrm{Id}$. at 304. The argument is elaborated in Choper, "Religion in the Public Schools," Minnesota Law Review, Vol. 47 (1963), pp. 329, 410.

11 See articles in n. 28, supra.

42 Kauper, "Church and State: Cooperative Separatism," Michigan Law Review, Vol. 60 (1961), pp. 1, 35: "It is apparent that the solution to some of these problems depends on placing the right label on the legislative program, and that if we can label a particular program as social or child welfare rather than aid to religious education, we thereby determine the constitutional result."

${ }^{43}$ Everson v. Board of Education, 330 U.S. 1, 18 (1947). 
On the other hand, Mr. Justice Jackson described the township's reimbursement plan as though it had been adopted solely as a result of importunities by Catholics to obtain financial assistance:

If we are to decide this case on the facts before us, our question is simply this: Is it constitutional to tax this complainant to pay the cost of carrying pupils to Church schools of one specified denomination? ${ }^{44}$

Neither of these descriptions is wholly correct or incorrect. Both, however, may be somewhat disingenuous, and surely it cannot be determined merely by studying the face of the ordinance which effect was in fact the primary one as intended by the council which adopted it. If the constitutional requirement is that a law affecting religion cannot stand unless it is supported by a primary and independent secular objective, it would seem imperative in situations such as this for the Court to attempt to discover which among several objectives actually provided the primary incentive for the law. If in fact the ordinance in Everson was merely the result of Catholic pressure for aid, for instance, the law would appear to be a product of the very kind of church-state collaboration which the First Amendment meant to discourage even if such collaboration is disguised as a "safety" law.

It is sometimes exceedingly difficult for courts to determine legislative purpose, especially in connection with state statutes enacted by legislatures which do not maintain a journal of debate or a record of committee hearings. The difficulty of the task should not be exaggerated, however, and ought not be confused with a judicial search of legislative motives. The motives of legislators more commonly concern their personal reasons for acting, e.g., sympathy or hostility to religion, desires to be reelected, etc., whereas their purpose in acting more substantially relates to the immediate objective to be accomplished by the law which is enacted. ${ }^{45}$

It is to be hoped that the Court will not belittle the Establishment Clause by rationalizing primary secular purposes from the face of laws they are called on to review, and by neglecting the essential inquiry into legislative facts. At the same time this technique of judicial abdication is available, and occasionally has been

44 Id. at 21.

${ }_{45}$ For an excellent discussion and reference to supporting cases, see Gomillion v. Lightfoot, 270 F.2d 594, 609-611 (5th Cir. 1959) (dissenting opinion), rev'd, 364 U.S. 339 (1960). used. In United States v. Kahriger, ${ }^{46}$ the Court sustained a federal statute which purported to be an exercise of the tax power applied to wagering transactions. But the legislative history of the statute indicated that it was not designed so much to raise revenue, a proper tax purpose, as to suppress gambling and to assist local governments in prosecuting gamblerspurposes clearly not among the delegated powers of Congress. In dissent, Mr. Justice Frankfurter took the legislative record into account and made the following observation which is equally relevant to the judicial review of church-state cases:

[W] hen oblique use is made of the taxing power as to matters which substantively are not within the powers delegated to Congress, the Court cannot shut its eyes to what is obviously, because designedly, an attempt to control conduct which the Constitution left to the responsibility of the States, merely because Congress wrapped the legislation in the verbal cellophane of a revenue measure. ${ }^{47}$

Similarly, in Barenblatt $v$. United States, ${ }^{48}$ the Court upheld the contempt conviction of a congressional committee witness who refused to answer questions which were logically relevant to a subject matter within the committee's investigative competence. In dissent, however, Mr. Justice Black carefully reviewed the record of the committee and concluded that the actual purpose in asking the questions was merely to expose the witness to public obloquy. ${ }^{49}$ Since this was the primary purpose of the questions, and such a purpose was not a proper function for the government, ${ }^{50}$ he voted

${ }^{46} 345$ U.S. 22 (1953).

${ }^{47} I d$, at 38 .

48360 U.S. 109 (1959).

${ }^{49} I d$. at $153-66$. For other cases in which the Court has deferred to Congress and has been satisfied with a mere rational nexus, see Howell, "Legislative Motive and Legislative Purpose in the Invalidation of a Civil Rights Statute," Virginia Law Review, Vol. 47 (1961), p. 439.

${ }^{50}$ Watkins v. United States, 354 U.S. 178, 200 (1957): "There is no congressional power to expose for the sake of exposure." See also Kilbourn v. Thompson, 103 U.S. 168 (1880); NAACP v. Alabama, 357 U.S. 449 (1958); Sweezy v. New Hampshire, 354 U.S. 234 (1957); Gibson v. Florida Legislative Investigation Committee, 372 U.S. 539, 545, 567 (1963); Uphaus v. Wyman, 360 U.S. 72, 82 (1959) (dissenting opinion). It is arguable, however, that while exposure is not a valid congressional purpose when the object of a legislative investigation is a private, volun- 
to reverse the conviction. In Justice Black's view, it was not enough that the questions could serve a proper governmental objective, if in fact it (a) also served unconstitutional objectives and (b) the legislature's primary purpose was to accomplish the latter. The same thing can be said in reviewing legislation which accomplishes a multiplicity of secular and religious objectives.

There is reason to anticipate that the Court will make a more assiduous inquiry into legislative purpose in future cases, at least where state laws are involved. ${ }^{51}$ In a number of the race cases, state laws which ostensibly served legitimate legislative objectives have been struck down when it became clear that they also served illegimate objectives which actually inspired the legislation. ${ }^{52}$ Similarly, in the most recent school prayer cases, Mr. Justice Brennan acknowledged that such prayers may have some secular effects wholly within the power of the state to promote, but he found that these, on closer examination, were not independent effects nor in fact the primary pur-

tary association, it may become so when the investigation is of a department of government.

Additionally, it remains true that some purpose other than exposure nearly always can be rationalized, and the dictum in Watkins has not yet become a holding if only for this reason: "The truth of the matter is that the balancing test, at least as applied to date, means that the Committee may engage in any inquiry a majority of this Court happens to think could possibly be for a legitimate purpose whether that 'purpose' be the true reason for the inquiry or not. And under the tests of legitimacy that are used in this area, any first-year law school student worth his salt could construct a rationalization to justify almost any question put to any witness at any time." Wilkinson v. United States, 365 U.S. 399, 420-21 (1961) (dissenting opinion).

${ }^{51}$ It has been ably argued that greater judicial self-restraint is justified in reviewing federal, rather than state, laws. Wechsler, "The Political Safeguards of Federalism: The Role of the States in the Composition and Selection of the National Government," Columbia Law Review, Vol. 54 (1954), p. 543.

52 See, e.g., NAACP v. Button, 371 U.S. 415 (1963); Shelton v. Tucker, 364 U.S. 479 (1960); NAACP v. Alabama, 357 U.S. 449 (1958); Yick Wo v. Hopkins, 118 U.S. 356 (1886); Gomillion v. Lightfoot, 270 F.2d 594, 606-11 (5th Cir. 1949) (dissenting opinion), rev'd, 364 U.S. 339 (1960); St. Helena Parish School Bd. v. Hall, 287 F.2d 376 (5th Cir. 1961). pose of the prayer. ${ }^{53}$ Even in the Sunday Closing Law Cases, the Court suggested that if the legislative history of such laws disclosed a primary religious inspiration for the enactment, rather than a general welfare purpose, such a law would offend the Establishment Clause:

We do not hold that Sunday legislation may not be a violation of the "Establishment" Clause if it can be demonstrated that its purpose-evidenced either on the face of the legislation, in conjunction with its legislative history, or in its operative effect-is to use the State's coercive power to aid religion..$^{54}$

It may be thought ironical that such an analysis may hold one law constitutional and another unconstitutional, when both operate in identical fashions in two different communities. Nevertheless, if one of the purposes of the Establishment Clause is to discourage attempts by organized religion to manipulate the civil process, certainly it is necessary and appropriate for the Court to determine whether such attempts accounted for the laws being reviewed. Any other approach to the subject invites religious establishment in cellophane packages, and would frequently make it empirically impossible to determine whether there was any primary secular objective being served by the law.

Alternative Means of Fulfilling Governmental Functions Without Pronounced Effects on Religion. To illustrate the importance of this consideration, it is useful to consider the controversy over aid to education. At the outset, it is certainly clear that state governments fulfil] a proper role by encouraging education through the enactment of attendance laws, the construction and operation of schools and universities, and by providing a host of auxiliary services such as transportation, books, counselling offices, recreation facilities, etc., as well as the basic paraphernalia of a school itself. Similarly, it is also virtually beyond question today that the federal government may assist and encourage these undertakings as it has in the historic grants of public lands, in providing National Defense, Fulbright, National Institute of Health and other scholarships, in providing research contracts which enable universities to add to their facilities, staff, and student bodies, etc. Virtually nothing in the current debate concerning aid to education

${ }^{53}$ School District v. Schempp, supra, at p. 280. See also the opinion for four members of the Court, by Mr. Justice Clark, at 224.

${ }^{54}$ McGowan v. Maryland, 366 U.S. at 453. 
raises a constitutional question challenging the power of Congress to assist education in general, although some may doubt its political wisdom and many disagree as to how extensive, or in what manner, such assistance might best be provided.

Granted that federal assistance to education would serve a proper governmental function, it might appear that the inclusion of parochial schools and colleges in such a program would not raise any serious constitutional issue either. For just as in Everson or the Sunday Closing Law Cases, any benefit which religious institutions might derive from such a program could be defended as merely incidental to a primary and independent secular purpose, and so long as the legislative record disclosed that Congress's paramount interest was really to foster education, rather than primarily to promote religion, the arrangement would appear to be valid.

The Supreme Court has suggested, however, that the requirement of church-state separation is not to be regarded so narrowly. It is not enough that a proper purpose was sincerely intended to be fulfilled by government, if that purpose could have been substantially fulfilled by other means which involve less effect on religion. The precept of the First Amendment is that government should attempt to promote the general welfare with the least effect on religion, and not merely that it should promote that welfare with but incidental, albeit substantial, effect on religion. Thus, in McGowan v. Maryland, Mr. Justice Frankfurter said:

If the value to society of achieving the object of a particular regulation is demonstrably outweighed by the impediment to which the regulation subjects those whose religious practices are curtailed by it, or if the object sought by the regulation could with equal effect be achieved by alternative means which do not substantially impede those religious practices, the regulation cannot be sustained. ${ }^{55}$

In the most recent school prayer cases, Mr. Justice Brennan made a similar observation:

But the teaching of both Torcaso and the Sunday Law Cases is that government may not employ religious means to serve secular interests, however legitimate they may be, at least without the clearest demonstration that nonreligious means will not suffice. ${ }^{56}$

The establishment issue in the proposals for federal aid to education consequently cannot

ss Ibid. at p. 462.

${ }^{66} 374$ U.S. 203 (1963) at 265. (Emphasis added) be resolved simply by asserting that "education" is the proper concern of government, and that since parochial schools also meet the secular standards of states or accrediting associations, their inclusion would be constitutional. What the issue requires is a more careful examination of: (a) the particular form of aid which may be provided, to determine whether its use is substantially confined to secular purposes; and (b) the feasibility of providing that aid through alternative means which involve less of a subsidy to religious institutions. Note, for instance, how differently the constitutional question might be answered depending upon which of the following types of federal aid proposals were adopted:

1. Congress appropriates one billion dollars for "education", to be disbursed by the Secretary of Health, Education and Welfare to each college which may receive a total grant equivalent to $\$ 500$ for each full time student. The money thus disbursed may be used according to each college's own determinations.

2. Congress appropriates one billion dollars for "education," to be disbursed by the Secretary of Health, Education and Welfare, upon the application of colleges demonstrating a need and specific plans for the construction of laboratories to be used exclusively for teaching and research in chemistry, physics, or engineering.

In the first case, a qualifying parochial college would be free to employ the funds thus granted to construct a chapel, to purchase additional copies of the Bible, in the teaching or subsidizing of aspiring ministers and priests, etc. In the second case, the funds are restricted so that the benefits to religion are markedly reduced. Such benefits are still conspicuous, however, in that the parochial college becomes more attractive to applicants by enjoying an enhanced physical plant, and private fundsfrom which the college otherwise derives its support-may now be released for wholly religious uses on campus. While the first case is almost clearly an instance of unconstitutional aid in view of the dicta of the Court, the second case appears arguable. A strict separatist might well argue that because parochial colleges account for only a small percentage of higher education, it is feasible for government to encourage education in the physical sciences in a substantial fashion by limiting its aid to public and nonparochial private colleges alone; since this is a feasible alternative means of carrying forward the primary secular objective without the same benefit to religion, the 
Establishment Clause requires that this is the way it must be done if it is to be done at all.

The difficulty is, however, that the Supreme Court itself has not vigorously pressed the alleged constitutional demand that government act to fulfill its proper functions with the least advantage or disadvantage to religion, and the issue of "alternative means" remains very much of an open question.

In Braunfeld v. Brown, ${ }^{57}$ the Court upheld a Sunday closing law even though the law made no exception for businessmen whose religious scruples obliged them to close on Saturday. The law thus operated against Sabbatarians to coerce them to offend their religious belief by opening on Saturday, at the risk of losing two days of business by closing both on Saturday and Sunday. When the anti-religious effect of the law was defended on the basis that it nevertheless served a proper secular purpose of setting one day aside for rest each week, the plaintiff rejoined that this could be accomplished equally well, without affecting his religion, by leaving the choice of the day to close to each entrepreneur. As a matter of fact, exceptions for Sabbatarians were already provided for in the majority of the thirty-four states having closing laws, and this was further evidence of their feasibility. Nevertheless, the Court rejected the sugestion and held that such an alternative means of effectuating the welfare policy of a closing law was not constitutionally required by the abridgment clause of the First Amendment. ${ }^{58}$

The closing cases also raised the same issue under the Establishment Clause. It was pointed out that the selection of Sunday as the day to close was of greater benefit to the Christian sects which predominated in the state, than would be the selection of some more neutral and less religious day, such as

\section{${ }^{57} 360$ U.S. 599 (1961).}

${ }^{58}$ In holding that an alternative day need not constitutionally be provided for Sabbatarians, Chief Justice Warren indicated that such an accommodation would not be a feasible alternative because of: (1) added costs and administrative difficulties in policing; (2) the business advantage it might provide for those electing to close on a different day and to open Sunday when competitors were closed; (3) the difficulty of determining the bona fides of those closing on a day other than Sunday; (4) the inability of family members and friends employed on Sunday to join with others not employed on Sunday; and (5) the general distraction from a day of uniform quiet and rest which some commercial activity might produce.
Monday or Tuesday. If the purpose of closing legislation was simply to assure a uniform day of rest for all persons within the community, this purpose could be equally accomplished, with less benefit to religion, by choosing some day other than Sunday. Even so, the Court did not invalidate the Sunday closing law or require that the state pursue its objective by the suggested alternative means. As a practical matter, the Court appears to reserve a large measure of discretion to the legislature, permitting it a good deal of latitude in selecting among means which carry more or less benefit or detriment to religion, while serving a primary secular purpose.

Indeed, a rigorous application of the "alternative means" idea might well have produced a different result in the Everson case, itself, the first case forthrightly to consider the Establishment Clause. If the purpose of the township was solely to promote safety in child transportation, and not also to assist parochial schools, that purpose might well have been served with less financial aid to the schools simply by enacting an ordinance requiring that school children be transported by regulated and licensed buses or automobiles. Since the state obviously has the power, and has often exercised it, to require that school buildings meet minimum safety standards without reimbursing the schools for the cost of meeting those standards, it could certainly proceed in the same fashion in regard to transportation. Yet, the availability of this alternative in Everson was not enough to invalidate the reimbursement plan adopted by the township, even though that plan obviously involved more of a benefit to the parochial schools by providing a $\$ 40$ a year reimbursement to parents.

We have already observed that Zorach $v$. Clauson is also irreconcilable with a rigorous "alternative means" test: if the purpose in releasing children from school was merely to give them an opportunity to attend religious classes should they choose to do so, that purpose would have been adequately served simply by releasing all students at certain hours. It would not necessitate keeping nonparticipating students in school, keeping records of those who were released to make certain that they attended church classes, or otherwise lending the public school apparatus subtly to coerce young students to attend religious classes.

With only eleven cases having been decided under the Establishment Clause, and with none dating farther back than 1947, it may not be surprising that the Court has not pressed an "alternative means" test. The fact that it 
was employed in the school prayer cases, however, and that it is now more frequently observed in the dicta of the Court, ${ }^{59}$ may indicate that it would be more useful in the future and that it is surely relevant to the controversy concerning federal aid to education.

Measuring the Net Effect of Governmental Activity on Religion. As cases have reached the Supreme Court, the controversy as to whether a given governmental activity unconstitutionally aided or harmed religious interests has too often confined itself to limited facts. Rarely have the litigants or the Justices examined the relation of those facts to other facts which may have occurred earlier to affect religious interests in one way or another. Yet, when the totality of related governmental transactions is considered, it may reasonably lead us to assess the net effect on religious interests differently than were we to concentrate only on one end of the transaction. This is especially clear when the governmental activity involves taxes and expenditures, but it may equally be so when the governmental activity involves a combination of regulations.

In Everson, for instance, the occasion for litigation was the expenditure of public funds in such a way as immediately to make it cheaper and easier for students to attend religious schools. By focusing only on the expenditure of funds, all members of the Supreme Court agreed that religion was "aided," and thus the issue was made to turn only on the question as to whether such aid was nonetheless constitutional because it was merely incidental to a primary and independent secular purpose which could not be equally fulfilled by means less beneficial to religion. The funds expended by the township in Everson necessarily came from some tax source, however, and the effect of the expenditure on religion cannot reasonably be determined in fact unless the effect of the tax which makes the expenditure possible is also considered.

If the expenditure came from an earmarked fund, the whole of which was derived exclusively from property taxes imposed on all real estate within the township, including the realty of churches, church schools, and of church members, it is clear enough that the raising of that fund initially operated as a burden to religion, i.e., it drained away some fiscal support which the church schools might have had in the absence of the tax. If the parents of parochial school children are subsequently included in a general reimbursement plan, the net effect of

${ }^{69}$ See text at nn. 55, 56 supra. the whole tax-and-spend transaction is substantially not one of "aid" to religion. Rather, it is substantially to restore financial support which was previously taken away by state action. In one sense, the net effect may even have placed religion at a slight disadvantage: had there been no tax in the first place, the additional money available to the church, freed from such taxes, could have been spent for exclusively religious purposes rather than for transportation. As it is, given these assumed facts, a court might well conclude that there was no establishment of religion because religion had received no substantial net advantage from the whole governmental transaction.

On the other hand, if the public fund from which transportation reimbursement was made came from property taxes which were not levied on church property, nor the property of persons sending their children to parochial schools, it would be much more clear that the inclusion of parochial school parents in the reimbursement plan did result in a substantial net advantage for religion. As the Everson case was actually decided by the Court, however, no member of the Court raised any question as to the source of the funds.

In reviewing proposals for federal aid to education, an effort to consider the whole transaction may also be helpful. The funds for such aid must probably come from taxes the great majority of which are imposed on personal and corporate income in the United States. The Internal Revenue Code, however, exempts the income of churches, church schools, church supported and church supporting enterprises from the income tax ${ }^{60}$ Moreover, it also provides that contributions to religious enterprises are tax deductible. ${ }^{61}$ Since the free exercise of religion is not especially affected adversely by income taxes, the inclusion of church schools among the recipients of tax funds would constitute governmental activity resulting in a net benefit or advantage to those schools. It is true, of course, that tuition payments to parochial schools are not currently tax deductible, and to this extent the income tax does operate to make it more expensive to attend a parochial school than would be the

${ }^{60}$ Internal Revenue Code of 1954, $\S 501$ et seq. See also $\$ 107$.

${ }^{61} I d$. at $\$ 170$. For the estate tax advantages of religious bequests, see $\$ 642$. For ways in which the charitable gift can be used to maximum advantage, see Lowndes, "Tax Advantages of Charitable Gifts," Virginia Law Review Vol. 46 (1960), p. 394. 
case if there were no tax, or if a deduction were allowed. On the other hand, the schools receive real and substantial indirect benefits from other governmental expenditures, simply as members of the national community, e.g., the general protection they receive from national defense. On balance, it would appear that tax accommodations already made in behalf of religion reinforce the argument that the inclusion of parochial schools in a federal education program would tend to establish religion, in the sense of producing a clear net benefit. If existing tax accommodations were removed, however, such a program would be more constitutional in net effect.

There is also reason to consider the total effect of governmental activity on religion, as well as the net effect of clearly related transactions as in the tax-and-spend situations. The gradual pervasion of American society by government has caused a number of religious organizations to fear that an unyielding "neutrality" in the First Amendment must inevitably result in the gradual shrinking of organized religion. In a very real sense, there is cause for this alarm: not because the Establishment Clause itself expresses any hostility toward religion, but simply because the "neutralized" zone of governmental activity continues to expand, gradually squeezing religion from larger and larger areas of the total environment.

From our previous discussion, it must surely be clear that distinctly religious practices and distinctly religious expenditures are forbidden to government by the requirement of the Establishment Clause. Distinctly religious practices or expenditures by private citizens and organizations, of course, are clearly not affected by the Establishment Clause and are theoretically protected by the abridgment clause. As government services expand, however, and as more of the economy and environment is occupied by the increasing, public, governmental sector of our society, the net effect of the shift is to confine religion to the ever shrinking domain of the relatively diminishing private sector. This does not mean that the private sector has become smaller absolutely, of course, but that more rapid growth in the public sector has resulted in a relative displacement of some previously private activities. A hundred years ago, for instance, the vast majority of colleges and universities were private. Not being subject to the First or Fourteenth Amendment, these colleges could pervade their curricula with religious emphases, as indeed many denominational colleges did. Today, the majority of colleges and universities are state supported, subject to the Fourteenth Amendment, and clearly not at liberty to engage in or to promote religious practices. We have witnessed a similar shift in secondary education as well, and the shift necessarily reduces the likelihood that the students who today spend more of their time within the public sector which is free of religious influences, will themselves become religious. What is true in education is equally true with respect to certain other parts of the total environment. To finance expanding government services, the combination of local, state and federal taxes may gradually divert an increasing fraction of total personal income, necessarily leaving proportionately less money in the private sector to each person to spend according to his individual choice, in support of religion or other undertakings. To the extent that the tax revenues thus collected may not be spent by government to support religious enterprises, but must be used exclusively for secular purposes, the net effect, arguably, is to reduce the relative supply of funds available to religion. ${ }^{62}$

None of this, to be sure, warrants the judicial junking of the establishment clause, or the abandonment of its salutary political objectives. It may indicate, however, that the First Amendment ought not be regarded as altogether religion-blind, i.e., absolutely forbidding government consciously to take religion into account. It surely makes reasonable, for instance, an exemption from compulsory attendance laws for children enrolled in parochial schools, at least where these schools

62 On the other hand, it is equally arguable that government fiscal activity, far from reducing disposable personal income, actually increases it. Funds taken in taxes are returned through the spending power to private hands which may then use the cash for religious or other purposes. And because of the enhanced multiplier effect which results from intelligent public expenditures, government fiscal policy obviously helps to generate more disposable personal income wholly within the private sector of the economy itself. Occasionally, in protecting the "free exercise of religion," the Court has ignored the substantial affirmative effects of governmental fiscal activity and has concentrated unduly only on the immediate, negative, "proximate" effects. See, e.g., Follett v. McCormick, 321 U.S. 573 (1944); Murdock v. Pennsylvania, 319 U.S. 157 (1943); Jones v. Opelika, 319 U.S. 103 (1943). See also Sherbert v. Verner, 374 U.S. 398, 83 S.Ct. 1790 (1963). 
meet minimum standards of education. ${ }^{63}$ Similarly, it will justify Sabbatarian exceptions to Sunday Closing Laws, even if such an exception may tend to provide the Sabbatarian with a slight economic advantage in being free to operate on a day during which some of his competitors may be closed. It may also support, although it may not require, some tax accommodations which currently exist in many state and federal laws, even when the taxes raised from others may be used in public undertakings of indirect benefit to those who did not contribute, e.g., to provide streets, parks, police, and fire protection, and to generate more disposable personal income. ${ }^{64}$

${ }^{63}$ See Pierce v. Society of Sisters, 268 U.S. 510 (1925), not decided, however, on the basis of the abridgment clause. See Kurland, Religion and the Law (1962), pp. 27-28.

${ }^{64}$ See Follett v. McCormick, 321 U.S. 573 (1944); Murdock v. Pennsylvania, 319 U.S. 105 (1943); Douglas v. Jeannette, 319 U.S. 157 (1943); Jones v. Opelika, 319 U.S. 103 (1943). See also Lundberg v. County of Alameda, 46
The neutrality of the First Amendment confronts difficult and unruly facts where it is frequently impossible for government to act without having some effect on religion, either tending to abridge its free exercise or to establish it. Nevertheless, by carefully attending to the net effect of government activity, by giving attention to the real purpose of such activity when it produces multiple effects, by remaining sensitive to alternative means available to the civil process and obliging government to select those which impinge upon religion least, we may more nearly abide by the underlying objectives of the First Amendment. While nothing offered here automatically resolves all issues where religious and state interests overlap or collide, the approach taken may at least avoid the simplistic dogmatism which frequently accompanies more facile treatments of the problem.

Cal. 2d 644, 298 F.2d 1, appeal dismissed, sub nom. Heisey v. County of Alameda, 352 U.S. 921 (1956). 